Louisiana State University

LSU Digital Commons

4-1-2017

\title{
Global networks for invasion science: benefits, challenges and guidelines
}

Jasmin G. Packer

The University of Adelaide

Laura A. Meyerson

University of Rhode Island

David M. Richardson

Stellenbosch University

Giuseppe Brundu

Università degli Studi di Sassari

Warwick J. Allen

Louisiana State University

See next page for additional authors

Follow this and additional works at: https://digitalcommons.Isu.edu/biosci_pubs

\section{Recommended Citation}

Packer, J., Meyerson, L., Richardson, D., Brundu, G., Allen, W., Bhattarai, G., Brix, H., Canavan, S., Castiglione, S., Cicatelli, A., Čuda, J., Cronin, J., Eller, F., Guarino, F., Guo, W., Guo, W., Guo, X., Hierro, J., Lambertini, C., Liu, J., Lozano, V., Mozdzer, T., Skálová, H., Villarreal, D., Wang, R., \& Pyšek, P. (2017). Global networks for invasion science: benefits, challenges and guidelines. Biological Invasions, 19 (4), 1081-1096. https://doi.org/10.1007/s10530-016-1302-3

This Article is brought to you for free and open access by the Department of Biological Sciences at LSU Digital Commons. It has been accepted for inclusion in Faculty Publications by an authorized administrator of LSU Digital Commons. For more information, please contact ir@lsu.edu. 


\section{Authors}

Jasmin G. Packer, Laura A. Meyerson, David M. Richardson, Giuseppe Brundu, Warwick J. Allen, Ganesh P. Bhattarai, Hans Brix, Susan Canavan, Stefano Castiglione, Angela Cicatelli, Jan Čuda, James T. Cronin, Franziska Eller, Francesco Guarino, Wei Hua Guo, Wen Yong Guo, Xiao Guo, José L. Hierro, Carla Lambertini, Jian Liu, Vanessa Lozano, Thomas J. Mozdzer, Hana Skálová, Diego Villarreal, Ren Qing Wang, and Petr Pyšek 


\title{
Global networks for invasion science: benefits, challenges and guidelines
}

\author{
Jasmin G. Packer • Laura A. Meyerson • David M. Richardson • Giuseppe Brundu • \\ Warwick J. Allen · Ganesh P. Bhattarai - Hans Brix - Susan Canavan - Stefano Castiglione • \\ Angela Cicatelli · Jan Čuda · James T. Cronin · Franziska Eller • Francesco Guarino • \\ Wei-Hua Guo • Wen-Yong Guo • Xiao Guo • José L. Hierro • Carla Lambertini • Jian Liu • \\ Vanessa Lozano • Thomas J. Mozdzer · Hana Skálová • Diego Villarreal • Ren-Qing Wang • \\ Petr Pyšek
}

Received: 13 July 2016/Accepted: 26 October 2016/Published online: 10 November 2016

(C) Springer International Publishing Switzerland 2016

\begin{abstract}
Much has been done to address the challenges of biological invasions, but fundamental questions (e.g., which species invade? Which habitats are invaded? How can invasions be effectively managed?) still need to be answered before the spread and impact of alien taxa can be effectively managed. Questions on the role of biogeography (e.g., how does biogeography influence ecosystem susceptibility,
\end{abstract}

Electronic supplementary material The online version of this article (doi:10.1007/s10530-016-1302-3) contains supplementary material, which is available to authorized users.

\section{J. G. Packer $(\square)$}

Environment Institute, The University of Adelaide,

Adelaide, SA 5005, Australia

e-mail: j.packer@adelaide.edu.au

J. G. Packer

School of Biological Sciences, The University of

Adelaide, Adelaide, SA 5005, Australia

J. G. Packer

Department of Environmental Systems Science, Institute of Integrative Biology, Swiss Federal Institute of

Technology (ETH), 8092 Zurich, Switzerland

\section{A. Meyerson}

Department of Natural Resources Science, The University of Rhode Island, Kingston, RI 02881, USA

\section{M. Richardson · S. Canavan}

Department of Botany and Zoology, Centre for Invasion Biology, Stellenbosch University, Matieland 7602, South Africa resistance and resilience against invasion?) have the greatest potential to address this goal by increasing our capacity to understand and accurately predict invasions at local, continental and global scales. This paper proposes a framework for the development of 'Global Networks for Invasion Science' to help generate approaches to address these critical and fundamentally biogeographic questions. We define global networks on the basis of their focus on research questions at the global scale, collection of primary data, use of standardized protocols and metrics, and commitment to long-term global data. Global networks are critical for the future of invasion science because of their

G. Brundu · V. Lozano

Department of Agriculture, University of Sassari, Viale Italia 39, 07100 Sassari, Italy

W. J. Allen · J. T. Cronin

Department of Biological Sciences, Louisiana State

University, Baton Rouge, LA 70803, USA

G. P. Bhattarai

Indian River Research and Education Center, University

of Florida, Fort Pierce, FL 34945, USA

H. Brix · F. Eller $\cdot$ C. Lambertini

Department of Bioscience, Aarhus University, 8000 Århus C, Denmark

S. Canavan

Invasive Species Programme, South African National Biodiversity Institute, Kirstenbosch Research Centre, Private Bag X7, Claremont 7735, South Africa 
potential to extend beyond the capacity of individual partners to identify global priorities for research agendas and coordinate data collection over space and time, assess risks and emerging trends, understand the complex influences of biogeography on mechanisms of invasion, predict the future of invasion dynamics, and use these new insights to improve the efficiency and effectiveness of evidence-based management techniques. While the pace and scale of global change continues to escalate, strategic and collaborative global networks offer a powerful approach to inform responses to the threats posed by biological invasions.

Keywords Biogeographic - Biological invasions · Collaboration · Global change · Global research network · Multitrophic $\cdot$ Transdisciplinary

\section{Introduction}

Considerable progress has been made on multiple fronts in understanding the many dimensions of invasion science (as defined by Richardson 2011). Despite such advances, the three fundamental questions that have driven most research on biological invasions since the 1980s have not been fully answered (Drake et al. 1989; Mooney et al. 2005): Which species invade? Which habitats are invaded? How can invasions be effectively managed? Plant

S. Castiglione - A. Cicatelli · F. Guarino

Department of Chemistry and Biology "A. Zambelli", University of Salerno, 84084 Fisciano, SA, Italy

J. Čuda · W.-Y. Guo · H. Skálová · P. Pyšek

Institute of Botany, The Czech Academy of Sciences,

Zámek 1, 25243 Průhonice, Czech Republic

J. Čuda $\cdot$ P. Pyšek

Department of Ecology, Faculty of Science, Charles

University, Viničná 7, 12844 Prague 2, Czech Republic

W.-H. Guo · X. Guo · R.-Q. Wang

Institute of Ecology and Biodiversity, School of Life

Sciences, Shandong University, Jinan 250100, People's

Republic of China

W.-H. Guo · X. Guo · R.-Q. Wang

Shandong Provincial Engineering and Technology

Research Center for Vegetation Ecology, Shandong

University, Jinan 250100, People's Republic of China invasions have been more intensively studied than any other major group of alien organisms (Pyšek et al. 2006, 2008) and have contributed most to our theoretical understanding of organism-focused (what determines invasiveness of particular taxa?) and ecosystem-centered (what makes a community, ecosystem or region susceptible to invasion?) questions in invasion science. Observations of invasions and associated biotic and abiotic processes have historically been important in informing invasion science (e.g., Richardson et al. 2004). More recently, manipulative experiments (garden and field-based), predictive modeling, and conceptual/theoretical approaches have helped to integrate our understanding of species invasiveness with that of community invasibility (Catford et al. 2009). Research areas contributing substantially to invasion science include the characteristics that predispose taxa to become invasive (van Kleunen et al. 2010; Guo et al. 2014; Suda et al. 2015) and interactions between biological invasions and environmental change at multiple scales (Walther et al. 2007; Pyšek et al. 2010; Kueffer et al. 2013). There is increasing realization that solutions to problems associated with invasions must be sought by placing the phenomenon firmly within the domain of social-ecological systems (Meyerson and Mooney 2007; Hui and Richardson 2017). Despite the progress, many fundamental questions in invasion science remain unresolved. Answers to the four research questions below are among those that hold the greatest potential to deepen our understanding of biological

X. Guo

College of Landscape Architecture and Forestry, Qingdao Agricultural University, Qingdao 266109, People's Republic of China

\section{J. L. Hierro}

Instituto de Ciencias de la Tierra y Ambientales (CONICET-UNLPam), 6300 Santa Rosa, Argentina

J. L. Hierro · D. Villarreal

Universidad Nacional de La Pampa, Ave Uruguay 151, RA-6300 Santa Rosa, Argentina

J. Liu

Institute of Environmental Research, Shandong University, Jinan 250100, People's Republic of China

T. J. Mozdzer

Department of Biology, Bryn Mawr College, Bryn Mawr, PA 19010, USA 
invasions and improve our capacity to manage invasion dynamics (see also Richardson 2011):

1. How does biogeography influence ecosystem susceptibility, resistance and resilience against invasion?

2. How does biogeography influence the ecological (e.g., enemy release and invasional meltdown) and socio-economic (e.g., dynamic travel and trade routes) mechanisms and impacts of biological invasions?

3. Are 'space for time' substitutions effective to predict the likelihood of an invasion, and the vulnerability of ecosystems to potential impacts, as the global environment continues to change?

4. What is the role of adaptation and evolution in determining invasion success, specifically:

a. evolutionary history within the native range prior to invasion?

b. adaptation to environments, and evolution, in the invaded range?

To facilitate progress on these global priorities for invasion science, researchers must consider which critical questions can realistically be answered (Strayer 2012; Kueffer et al. 2013) and then strategically collect and analyze data to address them. The vast spatial scale and breadth of experience required to address these big-picture questions presents a logistical challenge for research groups working in isolation. In this paper we focus on plant invasions to explore the benefits and challenges of addressing these otherwise intractable questions with global-scale research via transdisciplinary networks (sensu Wickson et al. 2006; see also Meyerson and Mooney 2007; Fraser et al. 2013) and provide a road map to encourage new, and more effective, international collaborations.

\section{Global networks for invasion science: a delimitation}

We define 'Global Networks for Invasion Science' through their primary purpose of collecting new primary data to answer specific questions about patterns, mechanisms and impacts of biological invasions at the global scale (e.g., the effect of sea level rise on the distribution of cosmopolitan littoral taxa) or finer resolutions that are best addressed by multiple regions contributing to a global synthesis (e.g., the effects of rising temperatures on the invasion of grasslands in arid biomes). Although most existing large-scale collaborations focus on a particular taxon (e.g., Ambrosia artemisiifolia, www.ragweed. eu) or specific invasion issues (e.g., effectiveness of sentinel plants as an early warning system; Roques et al. 2015), networks could also use model systems (e.g. Phragmites australis; Meyerson et al. 2016b) to accelerate deeper understanding of the patterns (e.g., changing spatial distributions; Dietz et al. 2006) and processes (e.g., the mechanisms by which invasive plants disrupt pollination networks; LopezaraizaMikel et al. 2007) of invasion dynamics.

To qualify as 'global', we suggest that networks cover gradients (e.g., latitudinal and longitudinal, and from natural to human-dominated ecosystem) with nodes (network partners and/or sites) spanning biogeographic zones over both hemispheres and including at least three continents. This suggestion is motivated by the need for a practical operational definition of networks for international-and potentially transdisciplinary-research teams that aim to study invasion dynamics at a representative set of locations and regions (Kueffer et al. 2013). Transdisciplinary refers to the generation of new knowledge and solutions to real-world problems through shared, standardized and iterative methodologies drawn from two or more disciplines (adapted from Wickson et al. 2006). The current distribution of most invasive organisms, in both their native and introduced ranges, spans two or more continents but rarely covers the entire globe (cf. Rejmánek and Richardson 2013). Limiting the selection of focal taxa to those that have a large global range would focus research efforts on a manageable set of cosmopolitan, model systems that are well-represented spatially and with good coverage in the literature (Table 1).

The objectives of Global Networks for Invasion Science can be summarized by four defining characteristics. (1) Global networks address research questions on biological invasions at the global scale (as defined above) through a biogeographic synthesis of insights from multiple localities across large regions (Hierro et al. 2005; Colautti et al. 2014b; Cronin et al. 2015). (2) Primary data on model systems are collected to address specific global questions, for example through common gardens, field experiments and/or field observations. Collaborations that use existing 
Table 1 Examples of species/genera which may make useful model organisms, their native and introduced distributions, and key characteristics which make them suitable candidate species for global network studies

\begin{tabular}{|c|c|c|c|}
\hline $\begin{array}{l}\text { Model organism } \\
\text { (Family) }\end{array}$ & Model system category & Distribution & Key characteristics \\
\hline $\begin{array}{l}\text { Acacia spp. } \\
\text { (Fabaceae) }\end{array}$ & $\begin{array}{l}\text { Intensively studied } \\
\text { species } \\
\text { Specialized research }\end{array}$ & $\begin{array}{l}\text { Native: Australia } \\
\text { Introduced: Africa, } \\
\text { Asia, EU, New } \\
\text { Zealand, NA, SA }\end{array}$ & $\begin{array}{l}\text { Multiple invasive and native species } \\
\text { Global distribution } \\
\text { Known invasion history } \\
\text { Habitat generalists } \\
\text { Vegetative reproduction (stem cuttings) } \\
\text { Interspecific hybridization } \\
\text { Major economic and environmental impacts } \\
\text { (displacement of native vegetation, disruption to water } \\
\text { flow leading to streambank erosion and changed } \\
\text { nutrient cycling patterns) }\end{array}$ \\
\hline $\begin{array}{l}\text { Alternanthera } \\
\text { philoxeroides } \\
\text { Alligator weed } \\
\text { (Amaranthaceae) }\end{array}$ & $\begin{array}{l}\text { Intensively studied } \\
\text { species }\end{array}$ & $\begin{array}{l}\text { Native: SA } \\
\text { Introduced: Asia, EU, } \\
\text { NA, Oceania }\end{array}$ & $\begin{array}{l}\text { Intraspecific genetic and phenotypic variability Global } \\
\text { distribution } \\
\text { Known invasion history } \\
\text { Habitat generalist } \\
\text { Vegetative reproduction (stem cuttings) } \\
\text { Fast growing } \\
\text { Major economic and environmental impacts (deleterious } \\
\text { effects on other plants and animals, water quality, } \\
\text { aesthetics, hydrology; degrades pasture, turf and crop } \\
\text { production in terrestrial ecosystems) }\end{array}$ \\
\hline $\begin{array}{l}\text { Ambrosia } \\
\text { artemisiifolia } \\
\text { Common } \\
\text { ragweed } \\
\text { (Asteraceae) }\end{array}$ & $\begin{array}{l}\text { Intensively studied } \\
\text { species } \\
\text { Specialized research }\end{array}$ & $\begin{array}{l}\text { Native: NA } \\
\text { Introduced: Africa, } \\
\text { Asia, EU, Oceania, } \\
\text { SA }\end{array}$ & $\begin{array}{l}\text { Pre-existing research network } \\
\text { Global distribution } \\
\text { Known invasion history } \\
\text { Habitat generalist } \\
\text { Fast growing } \\
\text { Major economic, environmental and social impacts } \\
\text { (decreases crop yield, displaces native species, } \\
\text { allergenic pollen) }\end{array}$ \\
\hline $\begin{array}{l}\text { Arundo donax } \\
\text { Giant reed } \\
\text { (Poaceae) }\end{array}$ & Understudied species & $\begin{array}{l}\text { Native: Asia } \\
\text { Introduced: Africa, } \\
\text { Asia, EU, NA, } \\
\text { Oceania, SA }\end{array}$ & $\begin{array}{l}\text { Global distribution } \\
\text { Known invasion history } \\
\text { Habitat generalist } \\
\text { Vegetative reproduction (rhizomes or plant fragments) } \\
\text { Fast growing } \\
\text { Major economic, environmental and social impacts } \\
\text { (outcompetes native species, alters hydrology and fire } \\
\text { regimes) }\end{array}$ \\
\hline $\begin{array}{l}\text { Colocasia } \text { spp. } \\
\text { Elephant ear/taro } \\
\text { (Araceae) }\end{array}$ & $\begin{array}{l}\text { Understudied species } \\
\text { Genera/families with an } \\
\text { underrepresentation of } \\
\text { invasive species }\end{array}$ & $\begin{array}{l}\text { Native: Asia } \\
\text { Introduced: Africa, } \\
\text { Asia, EU, NA, } \\
\text { Oceania, SA }\end{array}$ & $\begin{array}{l}\text { Multiple invasive and native species } \\
\text { Global distribution } \\
\text { Known invasion history } \\
\text { Habitat generalists } \\
\text { Vegetative reproduction (corm) } \\
\text { Fast growing } \\
\text { Interspecific hybridization } \\
\text { Major economic, environmental, and social impacts } \\
\text { (displacement of native vegetation, altered hydrology } \\
\text { and aesthetic qualities, agricultural crop) }\end{array}$ \\
\hline
\end{tabular}


Table 1 continued

\begin{tabular}{|c|c|c|c|}
\hline $\begin{array}{l}\text { Model organism } \\
\text { (Family) }\end{array}$ & Model system category & Distribution & Key characteristics \\
\hline $\begin{array}{l}\text { Eucalyptus spp. } \\
\text { (Myrtaceae) }\end{array}$ & $\begin{array}{l}\text { Understudied species } \\
\text { Genera/families with an } \\
\text { underrepresentation of } \\
\text { invasive species }\end{array}$ & $\begin{array}{l}\text { Native: Australia, Asia } \\
\text { Introduced: Africa, } \\
\text { Asia, EU, New } \\
\text { Zealand, NA, SA, EU }\end{array}$ & $\begin{array}{l}\text { Multiple invasive and native species } \\
\text { Global distribution } \\
\text { Known invasion history } \\
\text { Habitat generalists } \\
\text { Vegetative reproduction (stem cuttings) } \\
\text { Interspecific hybridization } \\
\text { Major economic and environmental impacts (loss of } \\
\text { native biodiversity, alteration of water and nutrient } \\
\text { regimes) }\end{array}$ \\
\hline $\begin{array}{l}\text { Lythrum salicaria } \\
\text { Purple loosestrife } \\
\text { (Lythraceae) }\end{array}$ & $\begin{array}{l}\text { Intensively studied } \\
\text { species } \\
\text { Specialized research }\end{array}$ & $\begin{array}{l}\text { Native: Africa, Asia, } \\
\text { Australia, EU } \\
\text { Introduced: New } \\
\text { Zealand, NA, SA }\end{array}$ & $\begin{array}{l}\text { Intraspecific genetic and phenotypic variability } \\
\text { Global distribution } \\
\text { Known invasion history } \\
\text { Habitat generalist } \\
\text { Vegetative reproduction (stem cuttings) } \\
\text { Fast growing } \\
\text { Interspecific hybridization } \\
\text { Major economic and environmental impacts (harmful to } \\
\text { livestock and crop production, alters hydrology and } \\
\text { nutrient cycling, displaces native species) }\end{array}$ \\
\hline $\begin{array}{l}\text { Opuntia spp. } \\
\text { Prickly pear } \\
\text { (Cactaceae) }\end{array}$ & $\begin{array}{l}\text { Genera/families with an } \\
\text { underrepresentation of } \\
\text { invasive species }\end{array}$ & $\begin{array}{l}\text { Native: NA, SA } \\
\text { Introduced: Africa, } \\
\text { Asia, EU, NA, } \\
\text { Oceania, SA }\end{array}$ & $\begin{array}{l}\text { Pre-existing research network } \\
\text { Multiple invasive and native species } \\
\text { Global distribution } \\
\text { Known invasion history } \\
\text { Habitat generalists } \\
\text { Vegetative reproduction (cladodes) } \\
\text { Interspecific hybridization } \\
\text { Major economic, environmental and social impacts } \\
\text { (harmful to livestock, native plant and arthropod } \\
\text { community, hinders human use of recreational areas, } \\
\text { cultivated crop) }\end{array}$ \\
\hline $\begin{array}{l}\text { Phragmites spp. } \\
\text { Common reed } \\
\text { (Poaceae) }\end{array}$ & $\begin{array}{l}\text { Intensively studied } \\
\text { species } \\
\text { Specialized research } \\
\text { Genera/families }\end{array}$ & $\begin{array}{l}\text { Native: Africa, Asia, } \\
\text { EU, NA, Oceania, SA } \\
\text { Introduced: NA, } \\
\text { Oceania }\end{array}$ & $\begin{array}{l}\text { Pre-existing research networks } \\
\text { Multiple invasive and native species } \\
\text { Intraspecific genetic and phenotypic variability } \\
\text { Global distribution } \\
\text { Known invasion history } \\
\text { Habitat generalists } \\
\text { Vegetative reproduction (rhizomes or plant fragments) } \\
\text { Fast growing } \\
\text { Intraspecific and interspecific hybridization } \\
\text { Major economic and environmental impacts (alters } \\
\text { hydrology, ecosystem function and degrades habitat for } \\
\text { native species) }\end{array}$ \\
\hline $\begin{array}{l}\text { Rumex spp. } \\
\text { Dock/sorrell } \\
\text { (Polygonaceae) }\end{array}$ & $\begin{array}{l}\text { Intensively studied } \\
\text { species } \\
\text { Genera/families with an } \\
\text { overrepresentation of } \\
\text { invasive species }\end{array}$ & $\begin{array}{l}\text { Native: Africa, Asia, } \\
\text { EU } \\
\text { Introduced: Africa, } \\
\text { Asia, NA, Oceania, } \\
\text { SA }\end{array}$ & $\begin{array}{l}\text { Multiple invasive and native species } \\
\text { Intraspecific genetic and phenotypic variability } \\
\text { Global distribution } \\
\text { Habitat generalists }\end{array}$ \\
\hline
\end{tabular}


Table 1 continued

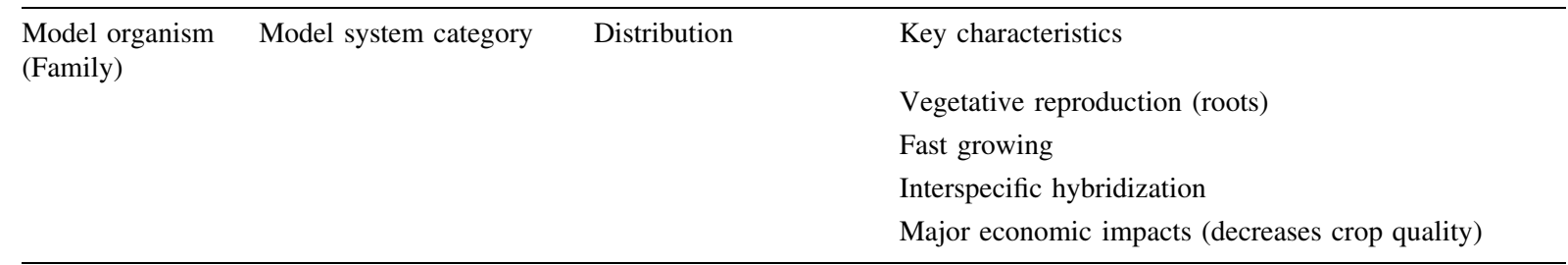

The model system categories are based on Kueffer et al. (2013), and distributions include Europe (EU), North America (NA), and South America (SA). Genera/families with an under-representation of invasive species enable phylogenetically controlled contrasts between native and invasive taxa, furthering understanding of mechanisms underlying invasion success. As pointed out by Kueffer et al. (2013), groups of species with an underrepresentation of invasive species have attracted less research interest, but understanding why these groups have not become invasive may help to advance invasion science significantly

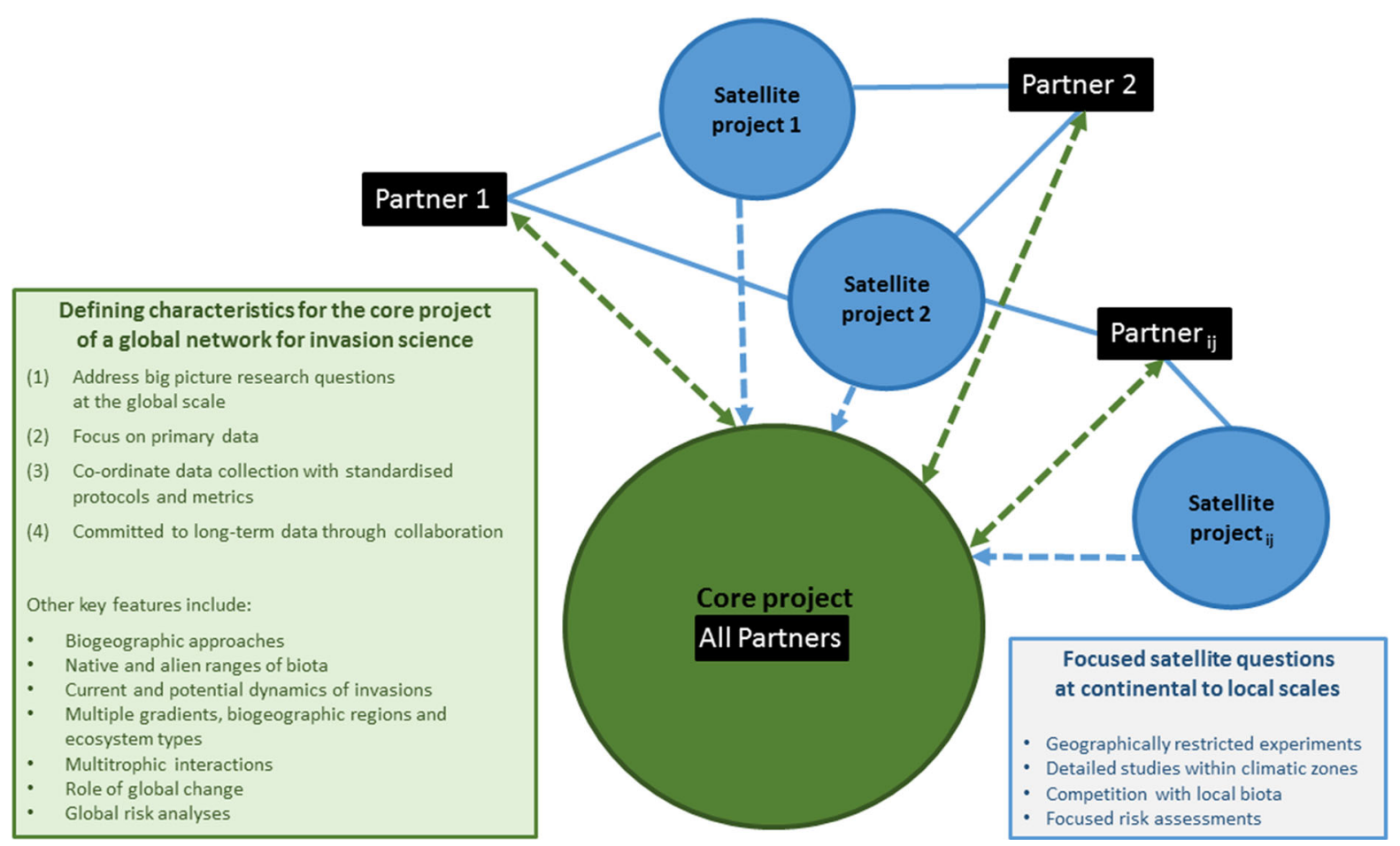

Fig. 1 Structure of a global network on invasive species. The core project (in green) involves all partners and addresses big picture research questions at the global scale through: collection of primary data; use of standardized protocols and metrics; and commitment to long-term global data. Knowledge, and iterative global research questions, are generated by the core project and are exchanged (green arrows) with all partners through mutual dialogue. Satellite projects (in blue) that are performed by

secondary information to answer global questions (e.g., GloNAF database of naturalized alien floras, van Kleunen et al. 2015, and international invasion monitoring, Latombe et al. 2016) are therefore not included in this definition. (3) Data collection is coordinated using standardized protocols and metrics (e.g., Wilson individual partners, or among partners, focus on questions that are biogeographically restricted to certain partner contexts or priorities (e.g., the competition of the focal taxa with a locally present congener, or addressing the effect of Mediterranean climates only). Satellite projects contribute (blue line) to the overall knowledge base within the core project; these inform the iteration of hypotheses and questions, some of which are addressed by other satellite projects

et al. 2014) that ensure comparability of data captured at different locations, and rigorous data analysis. (4) Global networks are enduring collaborations that collect long-term data over an agreed timeframe (e.g., 10 years) to address complex invasion dynamics. Ongoing networks may also initiate shorter-term 
"snapshot" satellite projects to address specific questions that relate to the main research direction of the respective network (see Fig. 1) (e.g., Richardson et al. 2011; Woodford et al. 2016).

\section{Why global networks are critical for invasion science}

Collaborative global networks are a powerful approach with many benefits for invasion science because they increase our collective capacity to: (1) set global priorities for research agendas (such as the strategic priorities we have outlined above); (2) identify and assess the risks that emerge from global trends; (3) unravel the mechanisms that mediate genetic diversity at multiple scales of space and time-the elucidation of such complexity cannot practically be achieved through experimental manipulation at a single site (Fig. 1); (4) understand biogeographic influences on the interactions between alien plants and other biota, both native and introduced, across different trophic levels; (5) build our collective capacity to predict future invasion dynamics; and (6) tap into the innovative approaches that diverse, transdisciplinary networks can generate to integrate new knowledge and evidence-based management of biological invasions.

Identifying and assessing the risk of emerging trends

Networks provide unparalleled opportunities to identify and assess emerging trends in the distribution patterns, ecology, genetics, and risk of the target taxa and their close relatives. Invasion processes are context-dependent and likely to evolve differently across biogeographic regions and environmental settings (Richardson and Bond 1991; Cronin et al. 2015; Packer et al. 2016). Some species or genotypes are therefore likely to vary in response to different environments (Meyerson et al. 2016a) suggesting that early warning signals of invasiveness could come from a single site rather than from multiple locations. For this reason, coordinated experiments that span bioclimatic zones on multiple continents can also utilize natural gradients to predict the influence of future climatic conditions.
Any emerging risks can be assessed rapidly through informal discussions (online and/or face-to-face) and more formal risk-assessment processes developed by the network or partner agencies. Active networks then have the opportunity to use the wider associations of members to notify the relevant policymakers, managers and broader community of the risk (nature and magnitude) and to present a clear, consistent plan on the appropriate priority actions, across multiple locations if necessary, to address the threat (e.g., Wilson et al. 2014 for Australian acacias).

Facilitating biogeographic insights into the genetics of invasion

A growing body of literature suggests that a biogeographical approach is fundamental to understanding the current and potential dynamics of invasions in their alien and native ranges (e.g., Hierro et al. 2005; Colautti et al. 2009; Hejda 2013; Parker et al. 2013; Cronin et al. 2015; Pyšek et al. 2015; van Kleunen et al. 2015). The distribution of genetic variation within taxa that have a broad geographic range (spanning several biogeographic regions and continents) is changing due to increased dispersal opportunities across continents and post-invasion evolution (e.g., Thompson et al. 2015 for Acacia saligna; see also Eriksen et al. 2014). Studies from single sites or regions cannot distinguish phenotypic variation in traits related to invasiveness (genotype $x$ environment interactions) from post-invasion adaptation and evolution (Maron et al. 2004; Hierro et al. 2013). There is increasing evidence that global change factors (such as warming, drought, precipitation, and their spatiotemporal variation) can alter macroevolutionary patterns and, eventually, the genetic diversity and structure of plant populations within just a decade (Avolio et al. 2013; Ravenscroft et al. 2015). A lack of information on intraspecific genetic diversity currently hampers our ability to understand potential responses of species to these global changes (Pauls et al. 2013; Meyerson et al. 2016b). It is not possible to accurately predict such responses by individual invasive species from isolated studies of local populations (which may not necessarily be representative of the fitness of the species in total, or of the genus) (Meyerson et al. 2010). The cultivation of a common set of genotypes representing intraspecific 
phylogeographic variation (e.g., the global genetic structure of a species) in combination with field studies of natural populations and common garden studies can simultaneously identify lineages of high fitness and the interaction of biogeographic factors crucial for the success of these lineages at a specific location. Global networks can thereby help to predict and monitor invasion risk even before potentially invasive genotypes are introduced to new areas accidentally or on a larger scale intentionally.

Establishing collaborative common gardens on all continents through a global network also provides an opportunity to assess the role of environmentally influenced genetic traits such as epigenetics (e.g., DNA methylation status; Schrey et al. 2013) and phenotypic plasticity in the adaptation and spread of potentially invasive plants. For instance, Guarino et al. (2015) demonstrated that ramets of the same clone of white poplar (Populus alba) had a different methylation status, and thus potentially different gene expression regulation and invasion risk, in relation to their geographical provenance on the island of Sardinia.

\section{Understanding biogeographic influences}

on trophic interactions

Global networks that focus on a model system can provide important insights into complex species interactions that limit or facilitate invasion processes. The geographic structuring of alien plant distributions (e.g., higher rate of invasions in temperate than tropical or polar regions; e.g., Lonsdale 1999; Fridley et al. 2007; van Kleunen et al. 2015) may intensify trophic interactions where alien species are more common (Iannone et al. 2016) and cause large-scale geographic shifts in species interactions and distributions (e.g., He et al. 2013; Lord and Whitlatch 2015). Invasional meltdowns may also be more common in regions where introductions are more likely. Long-term coordinated experiments across multiple biomes may help to identify anthropogenic drivers of change, including human-assisted introductions, and the mechanisms underpinning trophic interactions in response to these.

Herbivores and other natural enemies are widely recognized as having a strong influence on the establishment and subsequent spread of invasive plant species (Keane and Crawley 2002; Rogers and Siemann 2004; Jeschke et al. 2012). Controlled common garden experiments, one of the core approaches that can be used by global networks, are often performed to assess the importance of the Enemy Release Hypothesis at different localities (whether invasive species are more resistant to natural enemies than native species) and whether invasive species evolve in response to their natural enemies in their introduced range (e.g., Agrawal et al. 2005; Joshi and Vrieling 2005; Rapo et al. 2010). Coordinated research across multiple sites has also been influential in advancing our understanding of how climate change variables, plant genetics (genomic, ploidy and genotypic variation), epigenetics (e.g., variation in DNA methylation status), and geographic origins affect invasive/native plant-herbivore interactions (e.g., Lee and Kotanen 2015; Lu et al. 2015; Meyerson et al. 2016a).

Mutualisms play a key role in facilitating plant invasions (Richardson et al. 2000), but the roles of many symbionts in influencing progress at different stages along the introduction-naturalization-invasion continuum (sensu Richardson and Pyšek 2006) are poorly understood. Contrasting the levels of performance of the same species in different biogeographic regions is useful for understanding the roles of mutualisms in invasions. For example, cross-region comparisons have shed crucial light on the role of nitrogen-fixing bacteria in facilitating invasions of Australian Acacia species around the world and in determining the extent to which introduced legumes can form novel associations with resident bacteria (Rodríguez-Echeverría 2010; Ndlovu et al. 2013).

Predicting the future of invasion dynamics

Another incentive for globally coordinated research is the increased capacity to develop reliable predictions on invasive species responses to global change (incorporating both anthropogenic and climatic drivers) and future dynamics of their spread in general (Dukes and Mooney 1999; Guisan and Thuiller 2005). Predictive modelling could incorporate data from the network, including both data from natural invaded environments and responses from standardized common gardens. Identifying whether some characteristics predispose a species or genotype to naturalize or become invasive under projected future conditions would be particularly useful for biological security risk assessments and planning (Kolar and Lodge 2001; Meyerson and Reaser 2003; Pyšek and Richardson 2007; van Kleunen et al. 2010; Guo et al. 2014, 2016; 
Suda et al. 2015; Tho et al. 2016). The responses of plant functional traits across invasion stages differ (Pyšek et al. 2009, 2015) and can be used as predictors of response of an introduced species to multiple interacting global change factors (e.g., stages in the invasion process reached by the same species differ by region; Richardson and Pyšek 2012). The network approach offers the opportunity, by comparing the conditions under which the same alien taxa occur as casual, naturalized or invasive, to determine how the environmental context in a particular biogeographical setting interacts with functional traits in its invasion success.

Generating innovative solutions through diverse perspectives

A further benefit of global networks is their potential to overcome one of the greatest challenges within invasion science; translating new knowledge into action that will prevent or minimize biological invasions (Hulme 2003; Lindenmayer et al. 2008). The spread of invasive species globally is linked so closely to human influence that developing lasting, effective solutions to reverse this trend demands iterative and collaborative input from applied and fundamental perspectives (Wickson et al. 2006; see also Hulme 2006; Hui and Richardson 2017). Kueffer (2010) argues that transdisciplinary perspectives are not only desirable, but essential, because of the fundamentally socio-ecological aspects of plant invasions, including: (1) dynamic patterns of propagule pressure along evolving trade and transport routes; (2) the potential risk of novel organisms created through synthetic biology; and (3) variable human perceptions on the nature of invasions and the mechanisms underpinning them.

Better systems are needed to identify and assess these threats globally, to understand the underlying mechanisms, to develop and prioritize response actions, and communicate levels of threat and recommended interventions to policymakers and practitioners worldwide. The scale and breadth of these roles are clearly beyond the scope of a single research group, profession or discipline. Integrating theoretical and applied approaches can help to ensure that research questions address the most current and pertinent aspects of these global priorities, and that the management actions being implemented are the most effective and efficient.
To bridge the gap, where it exists, research scientists, policymakers and managers need to create new ways of exchanging knowledge and designing effective solutions together (Nassauer and Opdam 2008; Kueffer 2010; Ahern 2013; Richardson and Lefroy 2016). Global networks that span multiple approaches as well as continents have great potential to foster innovation by drawing on complementary expertise and experience on the focal issue or taxa (Max-Neef 2005; Pohl 2005; Wickson et al. 2006). The "virtual global acacia college" that was assembled in 2010-2011 to compile a collection of 20 papers on the invasion ecology of Australian acacias (Richardson et al. 2011) was a short-term demonstration of bringing together 104 researchers from 18 countries representing diverse subdisciplines in biology (e.g., genetics, invasion ecology, population ecology, plant pathology, plant physiology) and humanities (history, geography, philosophy) to develop a comprehensive overview of the many issues involved in acacia introductions and invasions. Although this initiative does not strictly correspond to our definition of a global network, it provides a tangible example of the benefits of invasion scientists working together across scientific disciplines.

Longer-term collaborations are needed to move from identification of issues to the implementation of effective solutions. The European Cooperation in Science and Technology (COST; www.cost.eu) Actions are bridging this gap with practical research outputs, such as the illustrated guide to invasive taxa and rapid assessments in the Mediterranean Sea (Zenetos 2015). The MIREN group (www. mountaininvasions.org) is well regarded for the innovative solutions it generates through long-term partnerships between scientists and practitioners across multiple continents. South African MIREN partners have contributed to developing an emerging global threats system to identify potential risks (e.g., pompom weed; Campuloclinium macrocephalum) and recommend management strategies to deal with outbreaks in KwaZulu-Natal Province (McDougall et al. 2011). More recently, MIREN has capitalized on long-term relationships and trust between network members to explore innovative ways to overcome the ecological and economic burden of international travel by reducing their face-to-face network meetings (Kueffer 2016). As it becomes increasingly difficult to access sufficient resources to cope with the growing 
Table 2 Examples of existing multilateral collaborations within invasion science (see also Box 2 in Lucy et al. 2016)

\begin{tabular}{|c|c|c|c|c|}
\hline Network name & Focus and scale & Status & Outputs (Expected or achieved) & Key citations \\
\hline $\begin{array}{l}\text { COST Action FP1401- } \\
\text { A global network of } \\
\text { nurseries as an early } \\
\text { warning system against } \\
\text { alien tree pests }\end{array}$ & $\begin{array}{l}\text { Consortium of over } 40 \\
\text { countries. Europe, EU } \\
\text { neighboring Countries and } \\
\text { Extra EU Countries }\end{array}$ & 2014-2018 & $\begin{array}{l}\text { Early warning system and } \\
\text { common protocols for alien } \\
\text { tree pests and diseases to be } \\
\text { established for countries } \\
\text { involved }\end{array}$ & Roques et al. (2015) \\
\hline $\begin{array}{l}\text { COST Action FA1203- } \\
\text { Sustainable } \\
\text { management of } \\
\text { Ambrosia artemisiifolia } \\
\text { in Europe } \\
\text { "SMARTER" }\end{array}$ & $\begin{array}{l}\text { Consortium of over } 40 \\
\text { countries. Europe, EU } \\
\text { neighboring Countries and } \\
\text { Extra EU Countries }\end{array}$ & 2013-2017 & $\begin{array}{l}\text { Long-term management and } \\
\text { monitoring protocols, } \\
\text { development of innovative } \\
\text { management solutions }\end{array}$ & www.ragweed.eu \\
\hline $\begin{array}{l}\text { COST Action TD1209 } \\
\text { European Information } \\
\text { System for Alien } \\
\text { Species "Alien } \\
\text { Challenge". }\end{array}$ & $\begin{array}{l}\text { Invasive Alien Species in } \\
\text { Europe. Consortium of over } \\
30 \text { countries. Europe, EU } \\
\text { neighboring Countries and } \\
\text { Extra EU Countries }\end{array}$ & 2012-2016 & $\begin{array}{l}\text { Knowledge gathering and } \\
\text { sharing through a network of } \\
\text { experts, support to a European } \\
\text { IAS information system, } \\
\text { implementation of EU } 2020 \\
\text { Biodiversity Strategy targets }\end{array}$ & $\begin{array}{l}\text { http://www.brc.ac. } \\
\text { uk/alien-challenge/ } \\
\text { home }\end{array}$ \\
\hline $\begin{array}{l}\text { European Information and } \\
\text { Research Network on } \\
\text { Aquatic Invasive } \\
\text { Species (ERNAIS) }\end{array}$ & $\begin{array}{l}\text { Online information system on } \\
\text { aquatic invasive species with } \\
\text { early warning functions and } \\
\text { decision support }\end{array}$ & $\begin{array}{l}\text { 2002- } \\
\text { current }\end{array}$ & $\begin{array}{l}\text { International cooperation in } \\
\text { research, scientific } \\
\text { information exchange and } \\
\text { management of aquatic } \\
\text { invasive species in Europe } \\
\text { and worldwide. }\end{array}$ & $\begin{array}{l}\text { http://www.reabic. } \\
\text { net/ERNAIS.aspx }\end{array}$ \\
\hline $\begin{array}{l}\text { Global Garlic Mustard } \\
\text { Field Survey (GGMFS) }\end{array}$ & $\begin{array}{l}16 \text { countries in North America } \\
\text { and Europe. Standardized } \\
\text { field measurements of } \\
\text { performance traits }\end{array}$ & $\begin{array}{l}\text { 2008- } \\
\text { current }\end{array}$ & $\begin{array}{l}\text { Replicating the GGMFS } \\
\text { approach with other invasive } \\
\text { species }\end{array}$ & $\begin{array}{l}\text { Colautti et al. } \\
\text { (2014a) }\end{array}$ \\
\hline $\begin{array}{l}\text { Global Invader Impact } \\
\text { Network }\end{array}$ & $\begin{array}{l}\text { Impact of invaders on } \\
\text { vegetation } \& \text { soil }\end{array}$ & $\begin{array}{l}\text { 2013- } \\
\text { current }\end{array}$ & $\begin{array}{l}\text { Experimental framework for a } \\
\text { standard methodology to } \\
\text { identify the ecological } \\
\text { impacts of invasive plants. }\end{array}$ & Barney et al. (2015) \\
\hline $\begin{array}{l}\text { Global Invasions } \\
\text { Research Coordination } \\
\text { Network }\end{array}$ & $\begin{array}{l}\text { International network of } \\
\text { scientists supported by the } \\
\text { U.S. National Science } \\
\text { Foundation addressing the } \\
\text { ecological and evolutionary } \\
\text { causes of biological invasions }\end{array}$ & Ongoing & $\begin{array}{l}\text { Coordination of both theoretical } \\
\text { and empirical research on } \\
\text { biological invasions around } \\
\text { the globe }\end{array}$ & $\begin{array}{l}\text { http://invasionsren. } \\
\text { si.edu/ }\end{array}$ \\
\hline $\begin{array}{l}\text { International Plant } \\
\text { Sentinel Network } \\
\text { (IPSN) }\end{array}$ & Plant pest and pathogens & Ongoing & $\begin{array}{l}\text { Early warning, standardized } \\
\text { methodologies for monitoring } \\
\text { and surveying of damaging } \\
\text { plant pests and pathogens, risk } \\
\text { analysis }\end{array}$ & $\begin{array}{l}\text { https://www.bgci. } \\
\text { org/plant- } \\
\text { conservation/ipsn/ }\end{array}$ \\
\hline INVASIVESNET & $\begin{array}{l}\text { International association for } \\
\text { open knowledge and open } \\
\text { data on invasive alien species } \\
\text { and their management }\end{array}$ & $\begin{array}{l}\text { 2016- } \\
\text { current }\end{array}$ & $\begin{array}{l}\text { Developing a sustainable } \\
\text { network of networks for } \\
\text { effective knowledge exchange }\end{array}$ & Lucy et al. 2016 \\
\hline $\begin{array}{l}\text { Mountain Invasions } \\
\text { Research Network } \\
\text { (MIREN) }\end{array}$ & $\begin{array}{l}\text { Effects of global change on } \\
\text { plant invasions and plant } \\
\text { biodiversity in mountainous } \\
\text { areas }\end{array}$ & $\begin{array}{l}\text { 2005- } \\
\text { current }\end{array}$ & $\begin{array}{l}\text { Database on invasive plant } \\
\text { distribution in mountain } \\
\text { environments }\end{array}$ & $\begin{array}{l}\text { Dietz et al. 2006; } \\
\text { McDougall et al. } \\
\text { (2011); www. } \\
\text { mountaininvasions. } \\
\text { org }\end{array}$ \\
\hline $\begin{array}{l}\text { Phragmites Network } \\
\text { (PhragNet) }\end{array}$ & $\begin{array}{l}\text { Addressing global scale } \\
\text { questions in ecology and } \\
\text { biological invasions through a }\end{array}$ & $\begin{array}{l}\text { 2014- } \\
\text { current }\end{array}$ & $\begin{array}{l}\text { Experimental framework and } \\
\text { standardized methodology } \\
\text { across common gardens to }\end{array}$ & $\begin{array}{l}\text { Meyerson et al. } \\
\text { (2016b) }\end{array}$ \\
\hline
\end{tabular}


Table 2 continued

\begin{tabular}{|c|c|c|c|c|}
\hline Network name & $\begin{array}{l}\text { Focus and scale } \\
\text { global network of common } \\
\text { gardens in Asia, Australia, } \\
\text { Europe, North America, and } \\
\text { South America }\end{array}$ & Status & $\begin{array}{l}\text { Outputs (Expected or achieved) } \\
\text { identify the ecological } \\
\text { impacts of invasive plants }\end{array}$ & Key citations \\
\hline $\begin{array}{l}\text { Southern Hemisphere } \\
\text { Network on Conifer } \\
\text { Invasions }\end{array}$ & $\begin{array}{l}\text { All aspects of conifer invasion } \\
\text { in the southern hemisphere }\end{array}$ & $\begin{array}{l}\text { 2007- } \\
\text { current }\end{array}$ & $\begin{array}{l}\text { Promotes interaction and } \\
\text { collaboration between } \\
\text { researchers, managers and } \\
\text { planners }\end{array}$ & $\begin{array}{l}\text { Richardson et al. } \\
\text { (2008); Simberloff } \\
\text { et al. (2010) }\end{array}$ \\
\hline
\end{tabular}

threat of invasive species globally, the imperative to find creative and collaborative ways to address this threat is also likely to grow.

\section{Building on existing and previous collaborations: challenges and lessons learned}

Good examples of multilateral research collaborations within invasion science exist already (McDougall et al. 2011; Colautti et al. 2014a). Some of the most extensive and important initiatives for both theoretical and applied research are summarized in Table 2. Past and current groups dealing with invasive species have mainly focused on plants rather than other organisms and have provided new tools for risk assessment and management, standardized protocols for data collection and management, and an avenue for different stakeholders to work together. Some of these global collaborations address the impact of invasive plants on a diverse range of taxa, such as the Global Invasions Research Coordination Network (www.invasionsrcn. si.edu), or The Global Invader Impact Network (https://weedeco.ppws.vt.edu/giin; Barney et al. 2015). Existing networks, focused on collecting primary data, are complemented by more technologybased collaborations. The Global Invasive Species Information Network (GISIN) was established to overcome the limitations of traditional approaches in responding to the growing demand for coordinated gathering, storing and disseminating information on introduced species (Ricciardi et al. 2000; Katsanevakis and Roy 2015). The GISIN has subsequently developed an online portal for standardized data (Jarnevich et al. 2015, http://www.gisin.org).

Establishing a productive and sustainable global research network presents many challenges, particularly in the areas of developing shared goals, expectations, coordination, communication, and funding (Gaziulusoy et al. 2016). Below we summarize the major stumbling blocks that can limit the long-term success of networks, and outline strategies to avoid or resolve these barriers (see Online Resource 1, Protocol Guidelines in Supplementary Material, for more information). Overcoming challenges requires shared learning and authentic collaboration amongst network members. One of the many potential strategies could be facilitating "progress reports" between invasion science networks to disseminate information about data protocols, governance, and preliminary outcomes from individual networks. This would enable data trends to be more readily detected, research priorities identified and promoted, and research approaches shared amongst the scientists involved. Ecology and Management of Alien Plant invasions (EMAPi; Richardson et al. 2010; Daehler et al. 2016), for example, has an international focus, holds conferences held every two years and could provide an accessible forum for invasion scientists to share and reflect on updates from other relevant networks. Another potential forum is the European Neobiota initiative (Kowarik and Starfinger 2009), which coordinates biennial conferences and the open-access journal NeoBiota which deals with biological invasions (Kühn et al. 2011).

Sustainability through communication and coordination

Successful global networks require active and continuing engagement of many collaborators (Petersen et al. 2014). Promoting long-term partnerships through collaborative, flexible governance can build trust and accommodate the various motivational levels and drivers over time of individuals members and the institutions they represent (Online Resource 1; see 
also Richardson and Lefroy 2016). Reaching agreement through collaborative processes for potentially divisive matters, such as data management (how to collect, store, integrate, analyze and use data) and authorship, is critical yet may be highly time-intensive for large global networks in particular. Failing to define and agree on a common research agenda and approach, and to communicate the importance of this to the scientific and broader community, are sure ingredients for failure in network initiatives.

Navigating the variability in biosecurity requirements across regions

Biosecurity legislation (international through to regional) and regulations of the donor (providing plant material) and host (receiving plant material for experiments and/or analysis) countries can strongly influence the feasibility and timeframes of initiatives. Hosting a garden with living, potentially weedy species or genotypes demands strict adherence to permit requirements, responsible husbandry practices, and countries may have vastly different standards and procedures to address biosecurity risks. Australia, New Zealand, South Africa and North America are renowned internationally for their strict biosecurity standards. Within China there are a range of biosecurity measures stipulated, such as the isolation buffer (natural or man-made to separate the garden from the surrounding area) and documentation of garden management that is required in some provinces but not necessarily in others. Networks that rely on sharing plant material need to resolve these biosecurity issues early in the planning process to allow adequate time for receiving and propagating material.

\section{Informing policy}

Biological invasions can only be reduced worldwide by engaging multinational support across all sectors of society. Global initiatives can help to bring these decision-making policies and processes into alignment with each other by improving the dialogue on complex scientific issues between researchers, policymakers, stakeholder networks and the broader public (Richardson and Lefroy 2016). The COST Action TD1209 "Alien Challenge" (www.brc.ac.uk/alien-challenge/ home) is one example of how a global collaboration within invasion biology can inform policy and stakeholders. This initiative is improving knowledge gathering and sharing through a network of experts informing the European Alien Species Information System (EASIN), including assessing the pathways and gateways of alien species introductions within Europe (Katsanevakis and Roy 2015). The knowledge gained from this initiative can be used to inform policy decisions and develop shared formats for alien species information in line with the EU 2020 Biodiversity Strategy targets, Regulation EU no. 1143/2014. The Invasive Species Specialist Group (ISSG) is another global community which combines scientific and policy experts on invasive species under the auspices of the Species Survival Commission (SSC) of the International Union for Conservation of Nature (IUCN, see review by Pagad et al. 2015). While these initiatives demonstrate some effective relationships between science and policy at high levels in Europe particularly, stronger science-policy partnerships are needed in other biogeographic zones.

Funding global networks

Active, productive networks need to be resourced over at least several years. While some activities can occur with in-kind resources or minimal funding (e.g., developing shared goals, establishing a core collection of plant material, and communicating through electronic media), others demand substantial investment of time and funding (e.g., meeting face-to-face, establishing experimental infrastructure, and field surveys). Only a small proportion of funding, if any, is likely to come from grants allocated to the whole network. Multilateral funding could include regional sources such as the European Union's Horizon 2020 and COST Actions which support collaborations with non-European Union research groups. More realistically, each network location will need to source its own funding, for example by identifying the synergies between network activities, ongoing or related research projects, and capitalizing on existing research networks and international funding opportunities. Several national or regional centers or institutes that focus on invasion science are now well established (e.g., the Laboratorio de Invasiones Biológicas in Chile-http:// www.lib.udec.cl/home.html; Department of Invasion Ecology of the Institute of Botany, The Czech Academy of Science-http://www.ibot.cas.cz/invasions; or the Centre for Invasion Biology, Stellenbosch 
University in South Africa-http://academic.sun.ac. $\mathrm{za} / \mathrm{cib} /$; van Wilgen et al. 2014). Such centers already function as hubs in global networks in invasion science, but there is scope for more focused global collaborations such as outlined in this paper.

\section{Conclusions}

The complexity and scale (spatial and temporal) of the most important biological invasion questions is well beyond the scope of individual biogeographic regions, disciplines, professions or local research groups. Despite the urgent need, only a few large-scale collaborations have been established within invasion science, and none have focused on these fundamental global (e.g., how does biogeography influence ecosystem resistance and resilience against invasion?) or highimpact applied (e.g., rapid responses to new threats) questions. Global Networks for Invasion Science are a powerful approach to address fundamental questions and transform this knowledge into appropriate policy and management recommendations. We encourage researchers, policymakers and practitioners to build global networks and generate the innovative solutions to minimize biological invasions that can only come from such a collaborative and global approach.

Acknowledgements We gratefully acknowledge the generosity of the University of Sassari, Italy, in hosting the PhragNet 2016 planning meetings and creating the space that facilitated this manuscript. DMR and SC acknowledge support from the DST-NRF Centre of Excellence for Invasion Biology and the Working for Water Programme through their collaborative research project on 'Integrated management of invasive alien species in South Africa' and the National Research Foundation of South Africa (Grant 85417 to DMR). SC's work was supported by the South African National Department of Environment Affairs through its funding of the South African National Biodiversity Institute Invasive Species Programme. HB, CL and FE were supported by the Danish Council for Independent Research I Natural Sciences (Project DFF-4002-00333). JTC, WJA and GPB were supported by NSF grant DEB 1050084 to JTC. LAM was supported by NSF DEB 1049914 to LAM and by the University of Rhode Island, College of Environment and Life Sciences. PP, JC, WYG and HS were supported by long-term research development project RVO 67985939 (The Czech Academy of Sciences), and Project No. 14-15414S (Czech Science Foundation). PP acknowledges support by Praemium Academiae award from The Czech Academy of Sciences. JGP warmly thanks the Institute of Integrative Biology, ETH Zürich for welcoming hospitality and the Environment Institute and Faculty of Sciences, The University of Adelaide for support from Travel Grant 13116630.

\section{References}

Agrawal AA, Kotanen PM, Mitchell CE, Power AG, Godsoe W, Klironomos J (2005) Enemy release? An experiment with congeneric plant pairs and diverse above- and belowground enemies. Ecology 86:2979-2989. doi:10.1890/05-0219

Ahern J (2013) Urban landscape sustainability and resilience: the promise and challenges of integrating ecology with urban planning and design. Landscape Ecol 28:1203-1212. doi:10.1007/s10980-012-9799-Z

Avolio ML, Beaulieu JM, Smith MD (2013) Genetic diversity of a dominant C-4 grass is altered with increased precipitation variability. Oecologia 171:571-581. doi:10.1007/s00442012-2427-4

Barney JN, Tekiela DR, Barrios-Garcia MN, Dimarco RD, Hufbauer RA, Leipzig-Scott P, Nuñez MA, Pauchard A, Pyšek P, Vítková M, Maxwell BD (2015) Global Invader Impact Network (GIIN): toward standardized evaluation of the ecological impacts of invasive plants. Ecol Evol 5:2878-2889. doi:10.1002/ece3.1551

Catford JA, Jansson R, Nilsson C (2009) Reducing redundancy in invasion ecology by integrating hypotheses into a single theoretical framework. Divers Distrib 15:22-40

Colautti RI, Maron JL, Barrett SCH (2009) Common garden comparisons of native and introduced plant populations: latitudinal clines can obscure evolutionary inferences. Evol Appl 2:187-199. doi:10.1111/j.1752-4571.2008.00053.x

Colautti RI, Franks SJ, Hufbauer RA, Kotanen P, Torchin M, Byers JE, Pyšek P, Bossdorf O (2014a) The Global Garlic Mustard Field Survey (GGMFS): challenges and opportunities of a unique, large-scale collaboration for invasion biology. NeoBiota 21:29-47. doi:10.3897/neobiota.21.5242

Colautti RI, Parker JD, Cadotte MW, Pyšek P, Brown CS, Sax DF, Richardson DM (2014b) Quantifying the invasiveness of species. NeoBiota 21:7-27. doi:10.3897/neobiota.21. 5310

Cronin JT, Bhattarai GP, Allen WJ, Meyerson LA (2015) Biogeography of a plant invasion: plant-herbivore interactions. Ecology 96:1115-1127. doi:10.1890/14-1091.1

Daehler CD, van Kleunen M, Pyšek P, Richardson DM (2016) EMAPi 2015: highlighting links between science and management of alien plant invasions. NeoBiota 30:1-3. doi:10.3897/neobiota.30.9594

Dietz H, Kueffer C, Parks CG (2006) MIREN: a new research network concerned with plant invasion into mountain areas. Mount Res Develop 26:80-81. doi:10.1659/02764741(2006)026[0080:MANRNC]2.0.CO;2

Drake JA, Mooney HA, di Castri F, Groves RH, Kruger FJ, Rejmánek M, Williamson M (eds) (1989) Biological invasions: a global perspective. Wiley, Chichester

Dukes JS, Mooney HA (1999) Does global change increase the success of biological invaders? Trends Ecol Evol 14:135-139. doi:10.1016/S0169-5347(98)01554-7

Eriksen RL, Hierro JL, Eren Ö, Andonian K, Török K, Becerra PI, Montesinos D, Khetsuriani L, Diaconu A, Kesseli R (2014) Dispersal pathways and genetic differentiation among worldwide populations of the invasive weed Centaurea solstitialis L. (Asteraceae). PLoS ONE 9:e114786

Fraser LH, Henry HAL, Carlyle CN, White SR, Beierkuhnlein C, Cahill JF Jr, Casper BB, Cleland E, Collins SL, Dukes 
JS, Knapp AK, Lind E, Long R, Luo Y, Reich PB, Smith MD, Sternberg M, Turkington R (2013) Coordinated distributed experiments: an emerging tool for testing global hypotheses in ecology and environmental science. Front Ecol Environ 11:147-155. doi:10.1890/110279

Fridley JD, Stachowicz JJ, Naeem S, Sax DF, Seabloom EW, Smith MD, Stohlgren TJ, Tilman D, Von Holle B (2007) The invasion paradox: reconciling pattern and process in species invasions. Ecology 88:3-17. doi:10.1890/00129658(2007)88[3:TIPRPA]2.0.CO;2

Gaziulusoy AI, Ryan C, McGrail S, Chandler P, Twomey P (2016) Identifying and addressing challenges faced by transdisciplinary research teams in climate change research. J Clean Prod 123:55-64. doi:10.1016/j.jclepro. 2015.08.049

Guarino F, Cicatelli A, Brundu G, Heinze B, Castiglione S (2015) Epigenetic diversity of clonal white poplar (Populus alba L.) populations: could methylation support the success of vegetative reproduction strategy? PLoS ONE 10(7):e0131480. doi:10.1371/journal.pone. 0131480

Guisan A, Thuiller W (2005) Predicting species distribution: offering more than simple habitat models. Ecol Lett 8:993-1009. doi:10.1111/j.1461-0248.2005.00792.x

Guo WY, Lambertini C, Nguyen LX, Li XZ, Brix H (2014) Preadaptation and post-introduction evolution facilitate the invasion of Phragmites australis in North America. Ecol Evol 4:4567-4577. doi:10.1002/ece3.1286

Guo WY, Lambertini C, Guo X, Li XZ, Eller F, Brix H (2016) Phenotypic traits of the Mediterranean Phragmites australis M1 lineage: differences between the native and introduced ranges. Biol Invasions 18:2551. doi:10.1007/ s10530-016-1236-9

He Q, Bertness MD, Altieri AH (2013) Global shifts towards positive species interactions with increasing environmental stress. Ecol Lett 16:695-706

Hejda M (2013) Do species differ in their ability to coexist with the dominant alien Lupinus polyphyllus? A comparison between two distinct invaded ranges and a native range. NeoBiota 17:39-55

Hierro JL, Maron JL, Callaway RM (2005) A biogeographical approach to plant invasions: the importance of studying exotics in their introduced and native range. J Ecol 93:5-15

Hierro JL, Eren Ö, Villarreal D, Chiuffo MC (2013) Non-native conditions favor non-native populations of invasive plant: demographic consequences of seed size variation? Oikos 122:583-590

Hui C, Richardson DM (2017) Invasion dynamics. Oxford University Press, Oxford

Hulme PE (2003) Biological invasions: winning the science battles but losing the conservation war? Oryx 37:178-193

Hulme PE (2006) Beyond control: wider implications for the management of biological invasions. J Appl Ecol 43:835-847

Iannone BV, Potter KM, Guo Q, Liebhold AM, Pijanowski BC, Oswalt CM, Fei S (2016) Biological invasion hotspots: a trait-based perspective reveals new sub-continental patterns. Ecography (in press, doi: 10.1111/ecog.01973)

Jarnevich CS, Simpson A, Graham JJ, Newman GJ, Bargeron CT (2015) Running a network on a shoestring: the Global
Invasive Species Information Network. Manage Biol Invasions 6:137-146. doi:10.3391/mbi.2015.6.2.04

Jeschke JM, Aparicio LG, Haider S, Heger T, Lortie CJ, Pyšek P, Strayer DL (2012) Support for major hypotheses in invasion biology is uneven and declining. NeoBiota 14:1-20. doi:10.3897/neobiota.14.3435

Joshi J, Vrieling K (2005) The enemy release and EICA hypothesis revisited: incorporating the fundamental difference between specialist and generalist herbivores. Ecol Lett 8:704-714

Katsanevakis S, Roy HE (2015) Alien species related information systems and information management. Manage Biol Invasions 6:115-117. doi:10.3391/mbi.2015.6.2.01

Keane RM, Crawley MJ (2002) Exotic plant invasions and the enemy release hypothesis. Trends Ecol Evol 17:164-170

Kolar CS, Lodge TS (2001) Progress in invasion biology: predicting invaders. Trends Ecol Evol 16:199-204

Kowarik I, Starfinger U (2009) Neobiota: a European approach. NeoBiota 8:21-28

Kueffer C (2010) Transdisciplinary research is needed to predict plant invasions in an era of global change. Trends Ecol Evol 25:619-620

Kueffer C (2016) A year without flying: the importance of virtual networking, The Mountain Blogs, Mountain Research Institute. Posted 22 January 2016. http://www.blogs-mri. org/a-year-without-flying/. Accessed 31 Aug 2016

Kueffer C, Pyšek P, Richardson DM (2013) Integrative invasion science: model systems, multi-site studies, focused metaanalysis, and invasion syndromes. New Phytol 200:615-633. doi:10.1111/nph.12415

Kühn I, Kowarik I, Kollmann J, Starfinger U, Bacher S, Blackburn TM, Bustamante RO, Celesti-Grapow L, Chytrý M, Colautti RI, Essl F, Foxcroft LC, García-Berthou E, Gollasch S, Hierro J, Hufbauer RA, Hulme PE, Jarošík V, Jeschke JM, Karrer G, Mack RN, Molofsky J, Murray BR, Nentwig W, Osborne B, Pyšek P, Rabitsch W, Rejmánek M, Roques A, Shaw R, Sol D, van Kleunen M, Vilà M, von der Lippe M, Wolfe LM, Penev L (2011) Open minded and open access: introducing NeoBiota, a new peer-reviewed journal of biological invasions. NeoBiota 9:1-12. doi:10. 3897/neobiota.9.1835

Latombe G, Pyšek P, Jeschke JM, Blackburn TM, Bacher S, Capinha C, Costello MJ, Fernández M, Gregory RD, Hobern D, Hui C, Jetz W, Kumschick S, McGrannachan C, Pergl J, Roy HE, Scalera R, Squires ZE, Wilson JRU, Winter M, Genovesi P, McGeoch MA (2016) A vision for global monitoring of biological invasions. Biol Cons. doi:10.1016/j.biocon.2016.06.013

Lee Y, Kotanen PM (2015) Differences in herbivore damage and performance among Arctium minus (burdock) genotypes sampled from a geographic gradient: a common garden experiment. Biol Invasions 17:397-408

Lindenmayer D, Hobbs RJ, Montague-Drake R, Alexandra J, Bennett A, Burgman M, Cale P, Calhoun A, Cramer V, Cullen P, Driscoll D, Fahrig L, Fischer J, Franklin J, Haila Y, Hunter M, Gibbons P, Lake S, Luck G, MacGregor C, McIntyre S, Mac Nally R, Manning A, Miller J, Mooney H, Noss R, Possingham HP, Saunders D, Schmiegelow F, Scott M, Simberloff D, Sisk T, Tabor G, Walker B, Wiens J, Woinarski J, Zavaleta E (2008) A checklist for ecological 
management of landscapes for conservation. Ecol Lett 11:78-91

Lonsdale WM (1999) Global patterns of plant invasions and the concept of invasibility. Ecology 80:1522-1536

Lopezaraiza-Mikel ME, Hayes RB, Whalley MR, Memmott J (2007) The impact of an alien plant on a native plantpollinator network: an experimental approach. Ecol Lett 10:539-550

Lord J, Whitlatch R (2015) Predicting competitive shifts and responses to climate change based on latitudinal distributions of species assemblages. Ecology 96:1264-1274

Lu XM, Siemann E, He MY, Wei H, Shao X, Ding J (2015) Climate warming increases biological control agent impact on a non-target species. Ecol Lett 18:48-56

Lucy FE, Roy H, Simpson A, Carlton JT, Hanson JM, Magellan K, Campbell ML, Costello MJ, Pagad S, Hewitt CL, McDonald J, Cassey P, Thomaz SM, Katsanevakis S, Zenetos A, Tricarico E, Boggero E, Groom QJ, Adriaens T, Vanderhoeven S, Torchin M, Hufbauer R, Fuller P, Carman MR, Conn DB, Vitule JRS, Canning-Clode J, Galil BS, Ojaveer H, Bailey SA, Therriault TW, Claudi R, Gazda A, Dick JTA, Caffrey J, Witt A, Kenis M, Lehtiniemi M, Helmisaari H, Panov VE (2016) INVASIVESNET towards an international association for open knowledge on invasive alien species. Manage Biol Invasions 7:131-139

Maron J, Vilà M, Bommarco R, Elmendorf S, Beardsley P (2004) Rapid evolution of an invasive plant. Ecol Monog 2:261-280. http://www.jstor.org/stable/4539056

Max-Neef MA (2005) Foundations of transdisciplinarity. Ecol Econ 53:5-16

McDougall K, Alexander J, Haider S, Pauchard A, Walsh N, Kueffer C (2011) Alien flora of mountains: global comparisons for the development of local preventive measures against plant invasions. Divers Distrib 17:103-111

Meyerson LA, Mooney HA (2007) Invasive alien species in an era of globalization. Front Ecol Environ 5:199-208

Meyerson LA, Reaser JK (2003) Biosecurity, bioterrorism, and invasive alien species. Front Ecol Environ 1:307-314

Meyerson LA, Viola D, Brown R (2010) Hybridization of invasive Phragmites australis with a native subspecies in North America. Biol Invasions 12:103-111

Meyerson LA, Cronin JT, Bhattarai GP, Brix H, Lambertini C, Lučanová M, Rinehart S, Suda J, Pyšek P (2016a) Do ploidy level and nuclear genome size and latitude of origin modify the expression of Phragmites australis traits and interaction with herbivores? Biol Invasions 2016:1-19. doi: 10.1007/s10530-016-1200-8

Meyerson LA, Cronin JT, Pyšek P (2016b) Phragmites australis as a model organism for studying plant invasions. Biol Invasions 2016:1-11. doi:10.1007/s10530-016-1132-3

Mooney HA, Mack RN, McNeely JA, Neville LE, Schei PJ, Waage JK (eds) (2005) Invasive alien species: a new synthesis. Island Press, Washington

Nassauer JI, Opdam P (2008) Design in science: extending the landscape ecology paradigm. Landsc Ecol 23:633-644

Ndlovu J, Richardson DM, Wilson JRU, Le Roux JJ (2013) Coinvasion of South African ecosystems by an Australian legume and its rhizobial symbionts. $\mathrm{J}$ Biogeogr 40:1240-1251

Packer JG, Delean S, Kueffer C, Prider J, Abley K, Facelli JM, Carthew SM (2016) Native faunal communities depend on habitat from non-native plants in novel but not in natural ecosystems. Biodiv Conserv 25:503-523

Pagad S, Genovesi P, Carnevali L, Scalera R, Clout M (2015) IUCN SSC Invasive Species Specialist Group: invasive alien species information management supporting practitioners, policy makers and decision takers. Manage Biol Invasions 6:127-135

Parker JD, Torchin ME, Hufbauer RA, Lemoine NP, Alba C, Blumenthal DM, Bossdorf O, Byers JE, Dunn AM, Heckman RW, Hejda M, Jarošík V, Kanarek AR, Martin LB, Perkins SE, Pyšek P, Schierenbeck K, Schlöder C, van Klinken R, Vaughn KJ, Williams W, Wolfe LM (2013) Do invasive species perform better in their new ranges? Ecology 94:985-994. doi:10.1890/12-1810.1

Pauls SU, Nowak C, Bálint M, Pfenninger M (2013) The impact of global climate change on genetic diversity within populations and species. Mol Ecol 22:925-946

Petersen AM, Pavlidis I, Semendeferi I (2014) A quantitative perspective on ethics in large team science. Sci Engin Ethics 20:923-945. doi:10.1007/s11948-014-9562-8

Pohl C (2005) Transdisciplinary collaboration in environmental research. Futures 37:1159-1178

Pyšek P, Richardson DM (2007) Traits associated with invasiveness in alien plants: where do we stand? In: Nentwig W (ed) Biological invasions, Ecological studies 193. Springer-Verlag, Berlin, pp 97-125

Pyšek P, Richardson DM, Jarošík V (2006) Who cites who in the invasion zoo: insights from an analysis of the most highly cited papers in invasion ecology. Preslia 78:437-468

Pyšek P, Richardson DM, Pergl J, Jarošík V, Sixtová Z, Weber E (2008) Geographical and taxonomic biases in invasion ecology. Trends Ecol Evol 23:237-244. doi:10.1016/j.tree. 2008.02.002

Pyšek P, Jarošík V, Pergl J, Randall R, Chytrý M, Kühn I, Tichý L, Danihelka J, Chrtek jun J, Sádlo J (2009) The global invasion success of Central European plants is related to distribution characteristics in their native range and species traits. Divers Distrib 15(5):891-903

Pyšek P, Jarošík V, Hulme PE, Kühn I, Wild J, Arianoutsou M, Bacher S, Chiron F, Didžiulis V, Essl F, Genovesi P, Gherardi F, Hejda M, Kark S, Lambdon PW, DesprezLoustau A-M, Nentwig W, Pergl J, Poboljšaj K, Rabitsch W, Roques A, Roy DB, Shirley S, Solarz W, Vilà M, Winter M (2010) Disentangling the role of environmental and human pressures on biological invasions across Europe. Proc Natl Acad Sci USA 107:12157-12162. doi:10. 1073/pnas.1002314107

Pyšek P, Manceur AM, Alba C, McGregor KF, Pergl J, Štajerová K, Chytrý M, Danihelka J, Kartesz J, Klimešová J, Lučanová M, Moravcová L, Nishino M, Sádlo J, Suda J, Tichý L, Kühn I (2015) Naturalization of central European plants in North America: species traits, habitats, propagule pressure, residence time. Ecology 96:762-774. doi:10. 1890/14-1005.1

Rapo C, Muller-Scharer H, Vrieling K, Schaffner U (2010) Is there rapid evolutionary response in introduced populations of tansy ragwort, Jacobaea vulgaris, when exposed to biological control? Evol Ecol 24:1081-1099

Ravenscroft CH, Whitlock R, Fridley JD (2015) Rapid genetic divergence in response to 15 years of simulated climate change. Glob Change Biol 21:4165-4176 
Rejmánek M, Richardson DM (2013) Trees and shrubs as invasive alien species-2013 update of the global database. Diversity Distrib 19:1093-1094

Ricciardi A, Steiner WWM, Mack RN, Simberloff D (2000) Toward a global information system for invasive species. Bioscience 50:239-244. doi:10.1641/00063568(2000)050[0239:TAGISF]2.3.CO;2

Richardson DM (2011) Invasion science: the roads travelled and the roads ahead. In: Richardson DM (ed) Fifty years of invasion ecology. The legacy of Charles Elton. WileyBlackwell, Oxford, pp 397-407. doi: 10.1002/ 9781444329988.ch29

Richardson DM, Bond WJ (1991) Determinants of plant distribution: evidence from pine invasions. Am Nat 137:639-668

Richardson BJ, Lefroy T (2016) Restoration dialogues: improving the governance of ecological restoration. Restor Ecol 24:668-673. doi:10.1111/rec.12391

Richardson DM, Pyšek P (2006) Plant invasions: merging the concepts of species invasiveness and community invasibility. Progr Phys Geogr 30:409-431

Richardson DM, Pyšek P (2012) Naturalization of introduced plants: ecological drivers of biogeographic patterns. New Phytol 196:383-396

Richardson DM, Allsopp N, D'Antonio CM, Milton SJ, Rejmánek M (2000) Plant invasions: the role of mutualisms. Biol Rev 75:65-93

Richardson DM, Rouget M, Rejmánek M (2004) Using natural experiments in the study of alien tree invasions: opportunities and limitations. In: Gordon MS, Bartol SM (eds) Experimental approaches to conservation biology. University of California Press, Berkeley, pp 180-201

Richardson DM, van Wilgen BW, Nunez MA (2008) Alien conifer invasions in South America: short fuse burning? Biol Invasions 10:573-577

Richardson DM, Daehler CC, Leishman MR, Pauchard A, Pyšek P (2010) Plant invasions: theoretical and practical challenges. Biol Invasions 12:3907-3911

Richardson DM, Carruthers J, Hui C, Impson FAC, Miller JT, Robertson MP, Rouget M, Le Roux JJ, Wilson JRU (2011) Human-mediated introductions of Australian acacias: a global experiment in biogeography. Diversity Distrib 17:771-787

Rodríguez-Echeverría S (2010) Rhizobial hitchhikers from Down Under: invasional meltdown in a plant-bacteria mutualism? J Biogeogr 37:1611-1622

Rogers WE, Siemann E (2004) Invasive ecotypes tolerate herbivory more effectively than native ecotypes of the Chinese tallow tree Sapium sebiferum. J Appl Ecol 41:561-570

Roques A, Fan J-T, Courtial B, Zhang Y-Z, Yart A, AugerRozenberg M-A, Denux O, Kenis M, Baker R, Sun J-H (2015) Planting sentinel European trees in Eastern Asia as a novel method to identify potential insect pest invaders. PLoS ONE 10:e120864

Schrey AW, Alvarez M, Foust CM, Kilvitis HJ, Lee JD, Liebl LB, Martin CL, Richards M, Robertson AW (2013) Ecological epigenetics: beyond MS-AFLP. Integr Comp Biol 53(2):340-350. doi:10.1093/icb/ict012
Simberloff D, Nuñez M, Ledgard NJ, Pauchard A, Richardson DM, Sarasola M, van Wilgen BW, Zalba SM, Zenni RD, Bustamante R, Peña E, Ziller SR (2010) Spread and impact of introduced conifers in South America: lessons from other southern hemisphere regions. Austral Ecol 35:489-504. doi:10.1111/j.1442-9993.2009.02058.x

Strayer DL (2012) Eight questions about invasions and ecosystem functioning. Ecol Lett 15:1199-1210. doi:10. 1111/j.1461-0248.2012.01817.x

Suda J, Meyerson LA, Leitch I, Pyšek P (2015) The hidden side of plant invasions: the role of genome size. New Phytol 205:994-1007. doi:10.1111/nph.13107

Tho BT, Sorrell BK, Lambertini C, Eller F, Brix H (2016) Phragmites australis: how do genotypes of different phylogeographic origin differ from their invasive genotypes in growth, nitrogen allocation and gas exchange? Biol Invasions 18:2563-2576. doi:10.1007/s10530-016-1158-6

Thompson GD, Bellstedt DU, Richardson DM, Wilson JRU, Le Roux JJ (2015) A tree well travelled: global genetic structure of the invasive tree Acacia saligna. J Biogeogr 42:305-314. doi:10.1111/jbi.12436

van Kleunen M, Weber E, Fischer M (2010) A meta-analysis of trait differences between invasive and non-invasive plant species. Ecol Lett 13:235-245

van Kleunen M, Dawson W, Essl F, Pergl J, Winter M, Weber E, Kreft H, Weigelt P, Kartesz J, Nishino M, Antonova LA, Barcelona JF, Cabezas FJ, Cárdenas D, Cárdenas-Toro J, Castaño N, Chacón E, Chatelain C, Ebel AL, Figueiredo E, Fuentes N, Groom QJ, Henderson L, Inderjit Kupriyanov A, Masciadri S, Meerman J, Morozova O, Moser D, Nickrent DL, Patzelt A, Pelser PB, Baptiste MP, Poopath M, Schulze M, Seebens H, Shu W, Thomas J, Velayos M, Wieringa JJ, Pyšek P (2015) Global exchange and accumulation of non-native plants. Nature 525:100-103. doi:10.1038/nature 14910

van Wilgen BW, Davies SJ, Richardson DM (2014) Invasion science for society: a decade of contributions from the Centre for Invasion Biology. S Afr J Sci. doi:10.1590/sajs. 2014/a0074

Walther GR, Gritti ES, Berger S, Hickler T, Tang ZY, Sykes MT (2007) Palms tracking climate change. Global Ecol Biogeogr 16:801-809

Wickson F, Carew AL, Russell AW (2006) Transdisciplinary research: characteristics, quandaries and quality. Futures 38:1046-1059. doi:10.1016/j.futures.2006.02.011

Wilson JRU, Caplat P, Dickie IA, Hui C, Maxwell BD, Nuñez MA, Pauchard A, Rejmánek M, Richardson DM, Robertson MP, Spear D, Webber BL, van Wilgen BW, Zenni RD (2014) A standardized set of metrics to assess and monitor tree invasions. Biol Invasions 16:535-551. doi:10.1007/ s10530-013-0605-x

Woodford DJ, Richardson DM, MacIsaac HJ, Mandrak NE, van Wilgen BW, Wilson JRU, Weyl OLF (2016) Confronting the wicked problem of managing biological invasions. Neobiota 31:63-86

Zenetos A. (ed.), 2015. Illustrated Guide of Marine Alien species in the Mediterranean for Students and Citizen Scientists. COST1209 Action: Alien Challenge, 22 pp 